University for Business and Technology in Kosovo

UBT Knowledge Center

UBT International Conference

2013 UBT International Conference

Nov 2nd, 12:00 PM - 12:15 PM

\title{
Building Typology In Kosovo Based On It's Thermal Characteristics
}

\author{
Luljeta Hoxha \\ Consult-Eng \\ Kadrush Latifj \\ Studio e projektimit LINKS 4 \\ Nafije Gashi \\ Studio e projektimit LINKS 4 \\ Lutfje Dervishi \\ KEDS
}

Follow this and additional works at: https://knowledgecenter.ubt-uni.net/conference

Part of the Architecture Commons

\section{Recommended Citation}

Hoxha, Luljeta; Latifj, Kadrush; Gashi, Nafije; and Dervishi, Lutfje, "Building Typology In Kosovo Based On It's Thermal Characteristics" (2013). UBT International Conference. 27.

https://knowledgecenter.ubt-uni.net/conference/2013/all-events/27

This Event is brought to you for free and open access by the Publication and Journals at UBT Knowledge Center. It has been accepted for inclusion in UBT International Conference by an authorized administrator of UBT Knowledge Center. For more information, please contact knowledge.center@ubt-uni.net. 


\title{
Building Typology In Kosovo Based On It's Thermal Characteristics
}

\author{
Luljeta Hoxha ${ }^{1}$, Kadrush Latifi ${ }^{2}$, Nafije Gashi ${ }^{3}$, Lutfije Dervishi ${ }^{4}$, \\ ${ }^{1}$ Consult-Eng, Prishtinë \\ 2 Studio e projektimit LINKS 4, Prishtinë \\ ${ }^{3}$ Studio e projektimit LINKS 4, Prishtinë \\ ${ }^{4}$ KEDS
}

\begin{abstract}
Each country should develop it's own building typology. For this purpose the state must have a system of classification defined by year of construction, building function and size of the existing buildings. It should then find examples that represent that category. The relevant data of these objects (external walls, windows, exterior doors, roof and slab above the ground), along with their respective photographs of buildings create countries typology. Its importance lies in the fact that when the object is being renovated regarding energy savings, rising the comfort or simply to maintain the structure of the building must know in advance some of the features of the building that are typical for its type.A typical classification of building stock will give professionals preliminary data for quick calculations on the potential energy savings, sustainability of the building structure, historical values etc. This paper will present the first steps in Kosovo for creating building typology and its application by analyzing existing projects in this field that were conducted from Kosovo Government, World Bank, EU and other NGO or Companies. The paper will also give best solutions for improving thermal characteristics by implementing Energy efficiency (EE) measures.

It will also show what are these measures and how will they affect heat transmission and energy consumption in general.
\end{abstract}

Keywords: Building typology, clasification, building structure

\section{Introduction}

Kosovo lack building typology catalogue which in most countries is a useful tool in determining energy saving potential by using specific categories in catalogue like year of construction, construction materials, types of windows installed, building size etc. In order to gain required information when working with countries building stock, some projects mostly financed from donors (ex. World Bank Kosovo Heat Market Study) have developed through surveys a classification of building stock being focused in energy performance on buildings. Also Ministry of Economic Development (MED) in 2011 made a study on countries public building stock (Study on Public Building Stock for Energy Auditing) being more focused in reported consumption and size of the building. Other relevant studies are also conducted from MED in last few years regarding energy consumption and distribution in a specific sector. The most relevant study is with focus on one branch of public sector such as "Study on distribution of energy consumption on service sector and possibilities for EE improvement". The relevance of this study lies on fact that it contains data on Public sector buildings and all the subsectors such as Education, Health, Commercial, Tourism etc.

\subsection{Typical clasification}

The most common classification criteria of a building stock are year of construction or period of construction. Each period is characterized by building system, building materials, heating system as main characteristics while there are also other not so important diversities.

\section{Classification as to the period of construction}


As to the WB study "Kosovo Heat market study" the following four periods of construction year were defined:

- Period 1: buildings built until 1959; basically pre FRY period

- Period 2: buildings built between 1960 and 1998;

- Period 3: buildings built between 1999 and 2001; emergency post war period

- Period 4: buildings built after 2002; end of emergency period and recent times.

Period one, three and four are fully determined, while period two covers a variety of buildings and it should have been explained in more details. Hence in order to have a more comprehensive view on building stock from this period it should be sub-divided.

In addition another classification is the classification as to the construction system

- Massive

- Skeleton

- Combined.

These construction systems are also linked to the building materials classification.

\subsection{First building period}

This period covers stock of buildings constructed prior to year 1959. These buildings are characterized with thick baring walls constructed with solid bricks, double pane windows, wooden board floorings without thermal insulation and ceilings consisting of plastered cane and wooden boards.

Because of wall thickness, these buildings consists of mostly 2-3 floors; openings (windows) are small in size hence lack of lighting comfort.

Most of these buildings have gone through a refurbishment, but, those that aren't refurbished should take under consideration following:

- Wall thickness usually fulfills the heat transmission values set in "Technical regulation for Energy savings in buildings" that requires value $\mathrm{U}<0.8 \mathrm{~W} / \mathrm{m} 2 \mathrm{~K}$. This means that no additional insulation is needed.

- If building is considered a cultural heritage, EE measures should be carried out only in close cooperation with official experts.

- Before any intervention, municipal or ministerial officials should evaluate the bearing capacity of the structure in order not to have refurbishment process if building is not considered stable.

Public buildings from this period share almost same specifics throughout Kosovo, while residential sector was less developed.

\subsection{Second building period}

This period should be divided in 1960-1979 and 1980-1999 due to changes in JUS (Yugoslav Standards) regarding energy efficiency.

Public buildings built betwen1960-1979 are characterized with new skeleton framing structure made of reinforced concrete. Walls are usually 25-30 thick with larger openings, hence larger glass mass comparing to full mass. Skeleton framing enabled multistory buildings. During this period prefabricated panels were introduced in construction sector but not widely applied. Clay hollow blocks were the most common building element. Thermal insulation was not applied even though designed. During '80-ties with new JUS code requiring a value $\mathrm{U}<1.25 \mathrm{~W} / \mathrm{m}^{2} \mathrm{~K}$, composite walls came to scene. These buildings are largely constructed in every town in Kosovo in form of Schools, Family health care centers, Kindergarten, Administration etc. They were characterized with large windows that span to the $1 / 2$ of building's facade, flat roofs and un-insulated concrete skeleton frame. Regarding EE, these buildings are big energy consumers due to glass/wall ratio, thermal bridges, un-insulated envelope etc. In other hand there is also a big potential for saving energy and whenever possible during EE implementation the glass mass should be reduced and substituted with insulated walls.

\subsection{Third building period}

The emergency period or post war period had sheltering as priority. The emergency period renovations 
in Kosovo were conducted in a non professional manner and with bad quality materials. Walls were left un-insulated while thermal insulation was only installed in new ceiling because it was less expensive then constructing new concrete slab. However there are cases that not even ceiling was insulated. Windows during emergency period were produced from wet wood which during first year of being mounted cracked due to contraction. At present, those windows do not close properly and air penetrates throughout their frame. Floors during this period were only covered with wooden boards which have rotten within first years of being installed. In order to extend their life cycle, personnel had them dyed with motor oil. Such an undertaking is not lawful as it is hazardous for health but was a necessity until next refurbishment.

\subsection{Fourth building period}

This period covers the new buildings constructed from 2003 and nowadays. Thermal measures are implemented in building envelope for almost all of the public buildings constructed during this period. However, the residential sector had different specifics regarding Energy conservation; multistory apartments are constructed in accordance with state standards while individual houses in majority do not implement energy conservation measures.

\section{Classification as to the building system}

- Massive

- Skeleton

- Combined

Massive building system was widely used until late 1960-ties. With baring walls constructed from full brick, these buildings could only go up to 4 floors. Wall thickness is different in each floor, with thicker in lower floors.

This construction system is used to construct buildings from the ottoman period (considered building heritage) and early Communist period.

It covers a wide span of buildings in terms of utility; public buildings (schools, municipal administration, hospitals etc) residential (dwellings, multistory apartments, dormitories, army barracks etc).

Skeleton building system has a reinforced concrete frame which consists from elements such as columns, beams and slabs. Its importance lies on releasing walls from bearing function. Hence, perimeter walls are usually $25-30 \mathrm{~cm}$ thick and openings or glass mass are unlimited in size. With no bearing walls, buildings rise to significant height.

This system has been widely adopted in Kosovo starting 1970-ies.It was used to construct dwellings in Prishtina, Mitovica, Gjilan, public buildings such as New Postal Office, KEK distribution building, Press Pallas (now Governmental Building) etc.

As to the wide span in time (1970-current) buildings constructed with this system represent various thermal characterics. As such it cannot be considered as a typical classification for the building stock. Combined system is mostly used for individual houses. It combines booth bearing walls and reinforced concrete frame. Thickness of bearing walls is reduced by the significant concrete masse used to fill clay hollow blocks. The combination of these systems comes more as a result of traditional craftsmanship than a real need for extra strength in structure. Thermal measures are not considered during construction and there is a significant EE potential.

\section{Classification as to the building materials}

As to the construction materials, buildings can be classified regarding four specific materials:

- Stone 
- $\quad$ Brick (hollow, full)

- Concrete

- Steel

These are only few of the materials used in construction, but there can be also other materials and subdivisions.

If built before 80-ies, the most common building material was full brick (1960) and perforated (hollow) brick during 1970 without outside insulation whatsoever. New building code enforced in 1982 acqu ired thermal transmittance of walls lower than $1.25[\mathrm{~W} / \mathrm{m} 2 \mathrm{~K}]$ which brought composite walls (perforated brick + façade brick) to the scene. Even then no thermal insulation was required and no attention was paid to thermal bridges. Most of the buildings built during ' 80 -ies have composite walls while perimeter concrete slabs and columns are left un-insulated and uncover with bricks creating this way a so called "Thermal bridge".

Until 80-ies roofs were constructed as flat roofs with a thin layer of thermal insulation covered with water insulation and gravel. However, later on these roofs were reconstructed as pitch roofs due to leakage problems. Whatever the thermal insulation was provided in original roof, it was damaged from leakage and from construction works carried out while reconstructing roof and during energy auditing it's thermal transmittance should be neglected as if there isn't any insulation.

Windows installed during '60-ties and '70-ties are double pane windows with single glass, while during '80-ies double glassed windows with aluminum frame were introduced. Such windows were produced in town of Suhareka, Kosovo for only a short period and stopped the production, which then left most of installed windows without spare parts hence damages couldn't be fixed. These windows were largely installed in public buildings. However, during the last decade public buildings have gone through a refurbishment process with mostly windows being changed with new PVC double glazed or wooden frame double glazed.

\section{Standards and regulations}

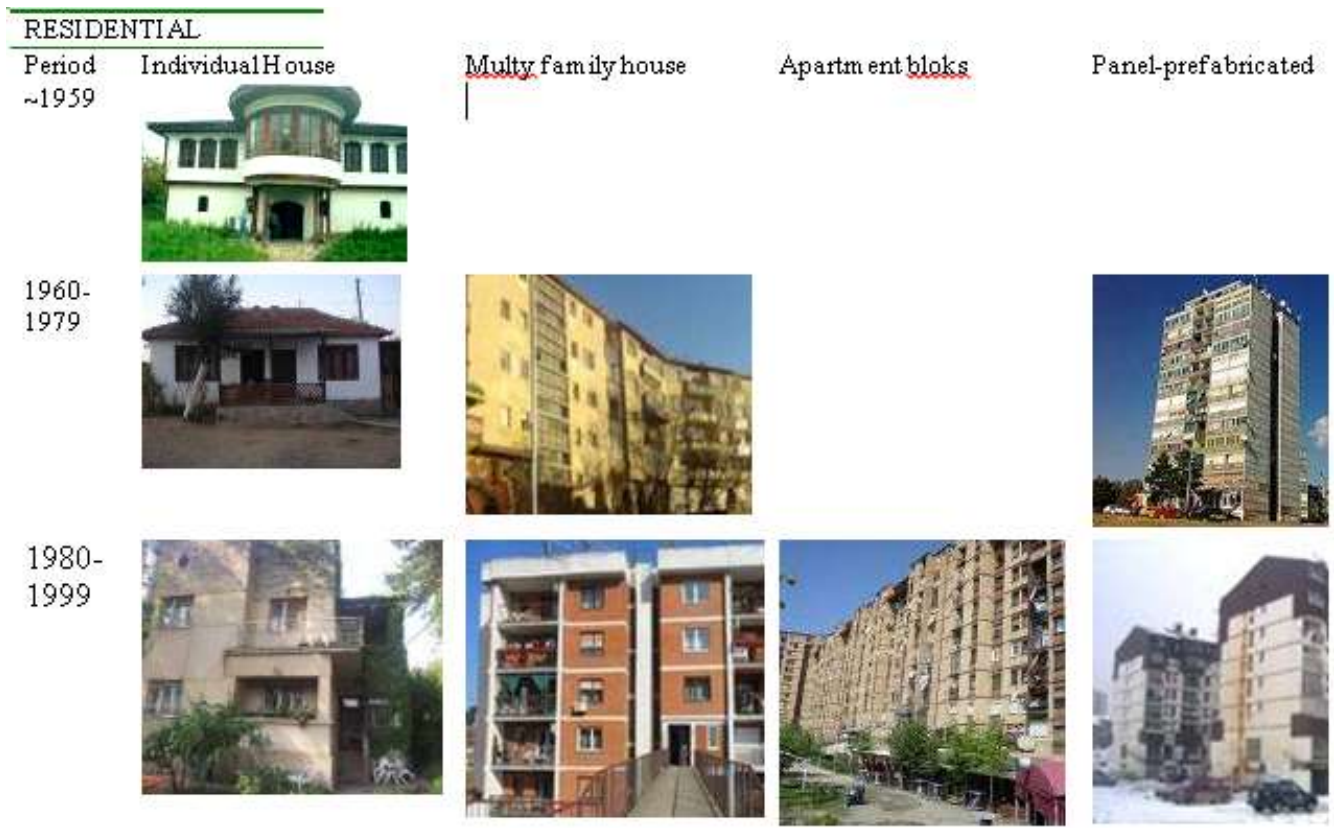




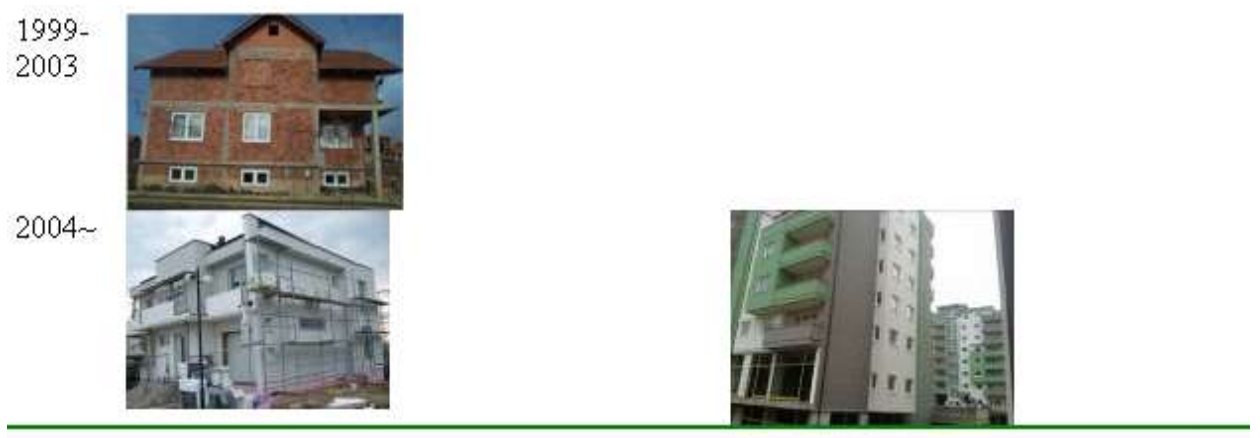

As to the World Bank study "Kosovo Heat market study", the first measures concerning heat conservation in the buildings in ex-Yugoslavia were issued in 1968. The "Proposal for maximal thermal transmittance" predicted three climates zones for the state. In accordance with the selected climate zone the maximal allowable thermal transmittance $\mathrm{k}(\mathrm{W} / \mathrm{m} 2 \mathrm{~K})$ was limited. The city of Prishtinë and most of Kosovo was classified in the third zone (III). The maximal allowable thermal transmittance was $\mathrm{k}=$ $1.37 \mathrm{~W} / \mathrm{m} 2 \mathrm{~K}$ (Official Gazette SFRJ 45/67). In the year 1970, the maximal allowable thermal transmittance coefficient was reduced down to $\mathrm{k}=1.28 \mathrm{~W} / \mathrm{m} 2 \mathrm{~K}$ (Official Gazette SFRJ 35/70).

A greater improvement concerning the heat conservation in buildings was achieved by the JUS.U.J5.600 code which was published in 1980. It was not only limited to the maximum allowable thermal transmittance but it took into consideration also other influences as minimal thermal stability of civil structures and vapor diffusion through the building outside walls. The maximal allowed thermal transmittance was significantly decreased. For Kosovo (climate zone III) it was limited to $\mathrm{k}=0.83$ $\mathrm{W} / \mathrm{m} 2 \mathrm{~K}$, which represented a reduction of about one third with respect to the regulation of 1970 . Calculation methods for thermal heat transfer coefficient, vapor diffusion and thermal stability of the civil structures were defined in the JUS.U.J5.510, 520 and 530 codes, also published in 1980.

In 1984, a new regulation"Rules for rational use of energy (Official Gazette SRS 31/84" was released in Slovenia due the reduction of the maximal allowable heat losses in Europe.

The regulation was included in the JUS.U.J5.600 code which was released in Yugoslavia in 1987. In the same year, the JUS.U.J5.510 code was amended.

However, during an inspection carried out in 100 public buildings conducted for a GIS ORF project " Preparation of methodology for M\&V of energy savings" it was experts task to review building design layouts and compare them with existing situation in order to evaluate a common heat transmission factor

It was concluded that JUS standards were not respected and enforced during construction with no insulation installed in building envelope though it was foreseen in building design. Same conclusion was made also during previous energy auditing projects emphasizing the lack of insulation materials in building envelope.

\section{Short proposed features for building catalogue}

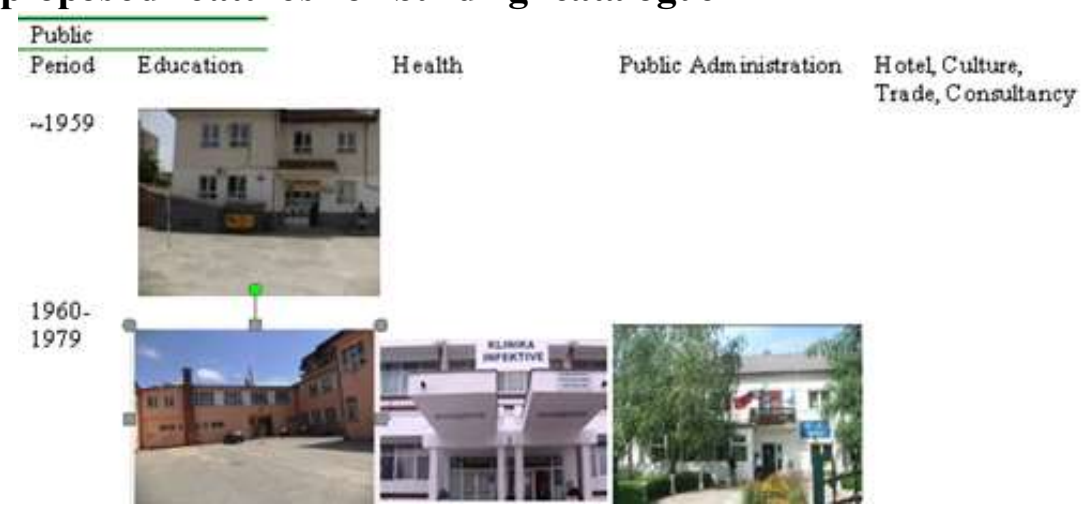




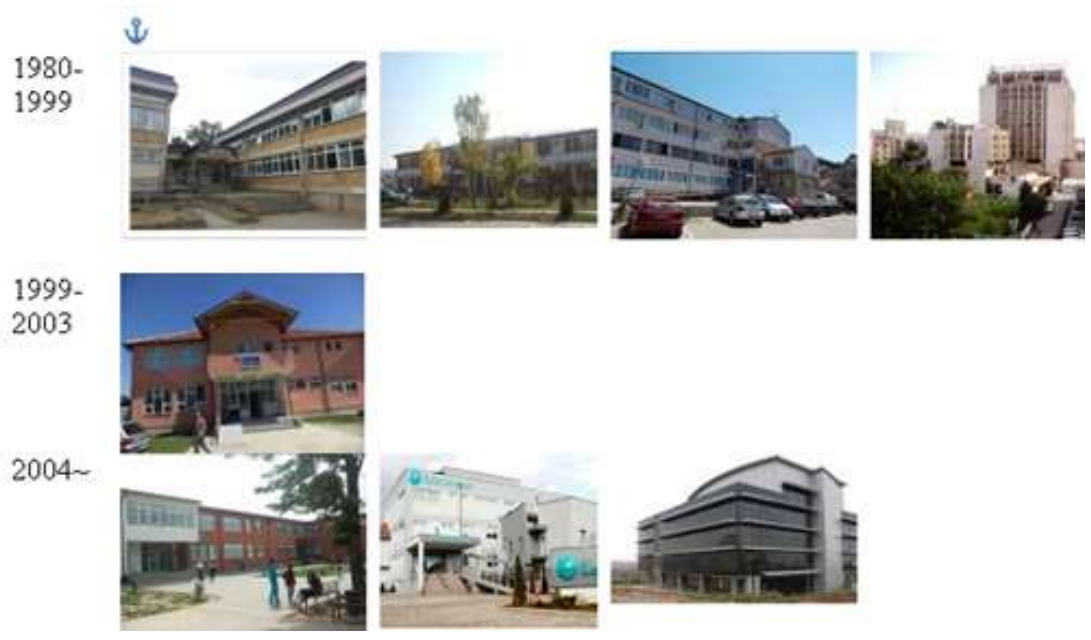

\section{Conclusions and recommendation}

It is very important for a country like Kosovo to have developed building typology and building catalogue. For such an undertaking officials should take the following steps:

- Analyze existing documents regarding description of building stock in country and neighboring countries especially former Yugoslavian republics.

- Analyze existing energy auditing of public and residential buildings

- Conduct surveys to cover a wider range of buildings that may not be part of existing audited buildings. Create the building typology and building catalogue.

\section{References}

1. The World Bank: "Kosovo Energy Sector - Heat Market Study";

2. NNP Studio Links 4: Study on Distribution of Energy Consumption in Services Sector and Possibilities for Energy Efficiency Improvement

3. Gashi N: Building Typology, Danish Management and Kantor "training for Energy Auditors"

4. Gashi N, Latifi K: UNDP "Training of Craftsmen on Building Insulation"

5. RregulloreTeknike 03/2009 PërEnergjiTermikedheMbrotjeTermikenëNdërtesa, MMPH Qeveria e Kosovës, Prishtinë 2009;

6. Rregullorja Nr. 01/2012 për Themelimin dhe Funksionimin e Komisionit për certifikim të auditorëve dhe menaxherëve të energjisë, MZHE;

7. Udhëzim Administrativ Nr. 14/2012 për Promovimin e Efiçiencës së Energjisë të përdoruesit fundor dhe shërbimet energjetike, MZHE, Prishtinë 2012; 